\title{
Book Review: History of Vocational Education and Training in Europe
}

\author{
Ruhi Tyson* \\ Stockholm University, Department of Education, 10691 Stockholm, Sweden
}

Published: 30.08 .2018

\section{Book Review}

History of Vocational Education and Training in Europe: Cases, Concepts and Challenges, edited by Esther Berner and Philipp Gonon, Peter Lang, Bern/Switzerland, 2016, 599 pp., ISBN 978-3-0343-2120-4, about 127€.

The book is volume 14 in the series Studies in Vocational and Continuing Education. Series editors are Philipp Gonon \& Anja Heikkinen. Volume 14, History of Vocational Education and Training in Europe: Cases, Concepts and Challenges is edited by Esther Berner, Professor for Educational Science, Helmut-Schmidt University in Hamburg, Germany, and Philipp Gonon, Professor for VET and Teacher Training, University of Zurich, Switzerland.

\section{Scope and Context}

The book consists of 29 chapters written by 38 authors. The overarching purpose is to provide a historical context for the development of vocational education and training (VET)-systems in Europe as this will aid in cross-country comparative studies where lack of historical context can lead to inaccuracies in comparisons. The basis for the contents are presentations given at a 2014 conference in Zurich with the same title as the book as well as some further chapters to provide a fuller picture. The VET systems covered by the book are: Austria, Denmark, England (and UK), Finland, France, Germany, Italy, Lithuania, Norway, Spain, Sweden and Switzerland, some once others in multiple chapters from different perspectives. As the subtitle reads, it is divided into three parts: concepts, cases and current challenges. The first part on concepts covers 11 chapters

${ }^{*}$ Corresponding author: ruhi.tyson@gmail.com

ISSN: $2197-8646$

http://www.ijrvet.net 
discussing different national approaches to VET from a historical perspective. The second part on cases covers 10 chapters that consider, in a more detailed manner, regional and/or national developments in a specific field as well as some comparative studies. The third part consists of 7 chapters on current challenges and discuss these from a historical perspective.

\section{Concepts}

The first contribution to this part has been written by Eric Verdier. It is a comparative study on systems of lifelong learning in France, Denmark and Great Britain as they have come to be influenced by the EU and OECD. In particular, he identifies four different conventions or systems of guidance in lifelong learning. One academic convention focusing on assigning individuals to existing educational pathways with a hierarchy that promotes academic achievement. One Neo-corporatist convention where the paths of lifelong learning are organized more through the labor market. One universal convention where social justice is an important component leading to a far-reaching integration of the vocational and the general. Finally the organized market convention where lifelong learning paths are mostly up to the individual to arrange. The comparisons then demonstrate that in practice countries have different hybrids of these conventions with the accompanying tensions.

The next chapter by Esther Berner, Philipp Gonon and Christian Imdorf looks at the origins of the Swiss VET system beginning in the late $19^{\text {th }}$ century. It explores the different trajectories of the cantons Lucerne and Geneva where in the former a system of dual-VET established itself whereas in the latter a fully school-based system took hold parallel to a dual one (a dual system being some form of VET located mostly in firms but also at schools). The conclusions are that different justifications prevailed in the two cantons based on the political and economic situation at the time. In Geneva a stronger emphasis on the civic aspects of VET contributed to the establishment of school-based VET but owing to economic constraints a parallel dual-system also took root. There was no comparative political drive towards the civic in Lucerne leading to a more complete dominance of a dual system.

The third chapter by Marius Busemeyer is a comparative study exploring the different trajectories that VET reforms have taken post-WWII in Sweden, Great Britain and Germany. Busemeyer argues that all three countries began from similarly organized VET systems but developed in very different ways owing to differences in the capitalist economy as well as in postwar politics. The main conclusion is that we benefit from a deeper knowledge of how economic and political influences shape VET in our striving to understand different national systems. This is highlighted by the differences in educational politics pursued in Germany by the conservative Christian Democrats and in Great Britian by the likewise conservative, but secular, Tories.

The fourth chapter by Philipp Gonon discusses the development of Swiss VET within the theoretical context of path-dependency oriented historical research and the critical junctures that have shaped Swiss VET. A particular focus is the rise of the Federal 
Vocational Baccalaureate in the 1990s which is explored more extensively as a critical juncture. The conclusions demonstrate that the critical junctures identified in the study are congruent with a path-dependency approach but create a layered system where, at each critical juncture, significant elements are added or modified in the institutional structure of VET.

The fifth chapter by Mathias Götzl and Thilo Ketschau is an analysis of the development of the Commercial School of the Trade Hall in Gotha, Thuringia between 1817 and 1902. With their analysis the authors demonstrate how the analytical use of theories and models of organizational sociology as well as neo-institutionalism can be profitably combined with the bottom-up approach of considering the development of a specific school. In contrast they argue, a top-down holistic approach would run the risk of failing to consider particular issues and problems relevant to the general development of VET at the time.

The sixth chapter by Lorenz Lasnigg explores the historical reasons for the remarkable stability of the Austrian VET system across different regimes. Through considerable political change it has retained a dualistic character with parallel apprenticeship- and school-based VET organizations that operate more or less independent of each other. Most of the changes found in the two VET systems can be attributed to a kind of "muddling throug" where small-scale decisions have slowly shifted the institutions without drastically and extensively reorganizing them. It concludes with a discussion on the relationship between the importance of critical junctures and small step pragmatic decision making in institutional change, questioning the strong divide between them in much theory.

The seventh chapter by Eveline Wittmann considers the development of vocational school policy in Germany. It uses a theoretical approach based in the concept of "legitimacy" in order to explore how the German state used its vocational school policy for these ends in particular when confronted with international frameworks such as the EQFs. It concludes that many school reforms can be understood as reactions to a contested legitimacy stemming from pressures outside of the nationstate.

The eighth chapter by Åsa Broberg focuses on the transition from work-oriented VET in early $20^{\text {th }}$ century Sweden to school-oriented VET after the reform of 1971 . It is argued that this can be understood in part as the shift between two figures of thought: work and school. These contain several polarities on the conceptual level which lead to changes in practice. This shift, it is concluded, is a pedagogical rather than institutional change, both systems being largely school-based and thus it is important to pay attention not only to institutional changes in VET reforms but also the pedagogical-conceptual changes that take place.

The ninth chapter by Esther Berner discusses two practices of subjectification in VET, selection by testing and training, in early 20th century Germany and Switzerland, from a Foucaultian genealogical perspective. Comparisons are made between the Taylorist and Fordist practices post WWI and contemporary neo-liberal discourses on employability concluding that some elements of discipline remain similar between then and now whereas the main character has shifted significantly from its Taylorist form to today's focus on flexibility, individuality, teamwork, etc. 
The tenth chapter by Manfred Wahle presents an argument for using more images in historical VET research. Using a series of paintings and photographs of early industrial work Wahle exemplifies this argument reaching the conclusion that we have, until recently, relied mostly on written documents in research and this could receive significant enrichment through the inclusion of images.

The eleventh chapter by Anja Heikkinen is a comparative study of VET in Finland, Great Britain and Germany in the period of the 1860s - 1960s. With this comparison the aim is to consider how competing views on the purpose of VET, as something contributing to livelihood, knowledge or companionship, have shaped the trajectories in the three countries. The main argument drawn from these comparisons is the need for shared research where the drive towards universalizing monologues in descriptions can be overcome.

\section{Cases}

In the section on case studies the first chapter by Elizabeth Flitner considers the German influences on the perception of apprenticeships in France during the Vichy regime. It is shown that the period experienced large shifts in VET policy that have not been sufficiently researched in order to examine their impact on the low-status that apprenticeship-forms of VET have to this day in France.

The second chapter by Gérard Bodé is a comparative case study between German and French VET systems in the period of 1860 - 1940. In this chapter Bodé discusses the processes behind the repeated French policy of the period of borrowing from German VET models. It is shown that this was done into a different more state-centric institutional structure and with the express purpose of legitimizing policy decisions already made. This largely contributed to the failure of models borrowed from Germany.

The third chapter by Antoine Vernet is a case study of how economic crises during the $20^{\text {th }}$ century have provided an opportunity for state intervention in French VET with the purpose of having VET contribute to the solution of these crises. It is suggested that this way of using VET has also contributed to its low status in the country.

The fourth chapter by Christian Helms Jørgensen, Svein Michelsen, Jonas Olofsson and Daniel Persson Thunqvist is a comparative case study of how the VET systems in the three Nordic countries, Denmark, Norway and Sweden came to develop between ca. 1850 and 1945. The three countries have developed substantially different systems, particularly when it comes to the role of apprenticeships and it is shown how these different trajectories depended heavily on the initial position of labor market organizations as well as on the degree to which vocational schools where established in the beginning of the period.

The fifth chapter by Marja-Leena Stenström and Maarit Virolainen deals with the development of the Finnish VET system from 1809 until today focusing on the development of a school-based VET system and the various consequences that this has had. In particular, they consider the comparative parity of esteem that has developed in Finnish society between VET and general upper secondary education. 
The sixth chapter by Svein Michelsen consists of a case study on the origins and early development of Norwegian VET between 1860 and 1930. The study pays particular attention to the various issues dividing stakeholders regarding its organization owing mainly to disagreements among business leaders and the inability of the strongly laissez faire political system to deal with this.

The seventh chapter by Tobias Karlsson, Fay Lundh Nilsson and Anders Nilsson is a case study from the Swedish VET context where two recent reforms, the new apprenticeships and the Teknikcollege, are compared. The discussion centers on the historical reasons for why the former has not been successful whereas the latter has met with more positive outcomes. The main arguments are that apprenticeships historically have been marginal in the Swedish VET context in contrast to the Teknikcollege which can look back at similarly organized initiatives from earlier in the $20^{\text {th }}$ century.

The eighth chapter by Lorenzo Bonoli is a study of the Swiss VET system and the process of implementing statistical overviews of its functions. It is argued that both the youth of statistics as a field of expertise as well as the initial difficulties with defining basic categories of VET like "apprenticeship" owing to a lack of clear regulation contributed to this.

The ninth chapter by Philipp Eigenmann and Michael Geiss is a case study on how apprentices articulated their needs and aspirations within the Swiss VET system between 1950 and 1980. It is demonstrated how associations, unions and official agencies all served to undermine the autonomous articulation of interests by apprentices. At the same time the apprenticeship system was under constant public scrutiny, something that still led to solutions being proposed for various issues albeit in a paternalistic way.

The tenth chapter by Chiara Marinelli is a study investigating the history of the industrial and artistic industrial schools in Italy between 1861 and 1913. The study provides a foundation for comparisons with how other VET systems developed in Europe at the time showing the relative ambition of the Italian institutions but also their low enrollment rate as well as the absence of working-class people in their classes. It is suggested that the failure of these schools might have two causes, one being knowledge of better alternatives for VET and one being the lack of diplomas that these institutions could give out. 0 pt

\section{Challenges}

In the section on challenges the first chapter by Friedhelm Schütte discusses the current state of research on the history of VET. One important reason for this is that transfer of VET systems from one country to another need to take into account the historical contexts within which they developed and this in turn requires an understanding of what historical research needs to cover. From this review a few important issues are highlighted. We need more research that analyses educational systems as a whole, this research needs to incorporate wider theoretical frameworks that take into account social, cultural and educational aspects capable of transcending domain-specific characteristics. There are also several methodological needs listed; international comparative 
studies, oral histories, biographical research and discourse analysis.

The second chapter by Simone Haasler looks at the gender segregation in the German labor market from a historical perspective. Based on a series of interviews with 24 German women aged $30-57$ regarding their professional and educational careers it is demonstrated that the historical pattern of welfare- and other social as well as educational policies has created institutional habits that are difficult to break.

The third chapter by Håkon Høst also has a gender-based perspective. Its focus is the historical development of VET in health and social care in Norway, looking at the changes that have followed from its transition from a school-based program to an apprenticeship-based one. Being the largest of the VET programs this has contributed to significant changes in the collective skills system compared to the traditional industrial and artisanal apprenticeships. Still, major differences remain where employers play a comparatively passive role in health and social care apprenticeships and where the training leads to assistant positions with low autonomy and prevalent part-time work.

The fourth chapter by Andreas Saniter and Vidmantas Tutlys is a comparative study of the developmental pathways in initial VET in Lithuania and Germany. The study demonstrates the challenge of systems-transfer, in this case the dual system from Germany to Lithuania in the 1990s owing to differences in institutional development from the late $19^{\text {th }}$ century onward. The conditions of the origin of the German apprenticeship system are shown to have been largely absent in Lithuania and it is argued that one of the main challenges in Lithuania is creating a similar tri-partite corporatist structure as that which prevails in Germany with powerful and self-confident employers' organizations, trade unions and chambers.

The fifth chapter by Linda Clarke and Jörn Janssen is a comparative study that focuses on the reasons why the VET systems in the post-war construction sector diverged in Britain and the Federal Republic of Germany. This, it is argued, rests largely on the very different nature of wage relations in the two countries. The consequences being that in the FRG qualification levels were linked to wages whereas in Britain the wages were increasingly unregulated and indifferent to skills and qualifications. The conclusions are that although both systems face challenges in todays globalized world, Germany seems better equipped to handle these than Britain because Britain lacks public institutional infrastructure for research, organization and supervision in order to restructure VET.

The sixth chapter by Ana-Inés Renta-Davids and Manel Fandos-Garrido is a historical study of the Spanish move from a predominantly school-based to a predominantly work-based VET system. Included is also an analysis of the efficiency of the VET system leading to a discussion of the main challenges it faces going forward: attracting students, engaging social agents and improving quality outcomes.

The final chapter by Bettina Siecke is a historical study of two-year training occupations in Germany, as distinct from the more common three years of the dual system. These shorter training options aiming at students with comparatively low school achievements are analyzed from the perspective of lifelong learning and permeability, ie. access to further education and qualifications. It is shown that continuous development has widened the scope of permeability but that challenges remain primarily because of companies' selection principles. 


\section{Conclusion}

The book has an impressive scope, covering macro-perspectives as well as micro-perspectives on the history of VET in Europe. A significant number of chapters are also comparative giving the reader a good view of the contrasting VET systems in Europe and the historical processes that have contributed to this diversity. Several of the cases demonstrate clearly how dependent the VET system of a country is on political and economic conditions and how difficult it can be to effect changes without taking this into account. Several cases also point to the impact that cultural and conceptual conditions in a country can have on the development of VET. Together these provide a rich description of the complexity involved in the development of educational systems. A number of cases also focus on specific elements in a country's VET thereby demonstrating how diverse vocational education often is when one looks beyond the generalized descriptions in many publications with such a wide scope as this one.

The anthology format and broad focus on principles, cases and challenges presents the reader with an unusual plurality of historical methods and perspectives as well as research aims. This makes the publication doubly valuable, both as a guide to the history of VET in Europe and as an overview of historical research including its varying methods and current issues. Simply summarizing the many suggestions and calls for further research provides one a significant insight into the future potential of historical studies.

As an anthology its plurality of voices also serve to avoid the critique launched already in the 1930s by Ludwik Fleck that handbooks written as monographs often aim at a critical synopsis that masks some of the multiplicity found in scientific journals. The variety of perspectives in this anthology supports the reader in developing an understanding for European VET that is not simplified. This does come at the cost of some coherence and ease of reading but is well worth it. For a scholar or student wanting to get a broad view of the history of VET in Europe including the various ways that historical research can contribute to our understanding of contemporary issues in VET the volume is indispensable.

\section{Biographical Note}

Dr Ruhi Tyson, is a senior lecturer at the Department of Education, Stockholm University, Sweden as well as at the Waldorf University College, Sweden. His research interests focus on Vocational Bildung from a biographical and narrative perspective as well the combination of Bildung, practical wisdom and didactics. 